\title{
THE BIOLOGICAL SIGNIFICANCE OF THE ANOMALOUS SERUM AND URINARY PROTEINS OF MYELOMATOSIS, LYMPHOMA, AND OTHER CONDITIONS
}

\author{
BY \\ J. A. OWEN AND C. GOT \\ From the Clinical Biochemical Laboratories, St. Vincent's Hospital, Melbourne, and the \\ Department of Biochemistry, University of Melbourne
}

(RECEIVED FOR PUBliCATION MAY 25, 1959)

The frequent occurrence of protein anomalies in patients with myelomatosis has long been recognized. Bence Jones reported on the unusual urinary protein of a patient with this disease over a hundred years ago (Bence Jones, 1848). Hyperproteinaemia in myelomatosis was recorded somewhat later (Ellinger, 1899). Subsequently, electrophoretic studies have shown that the hyperproteinaemia is due to the presence in serum of a protein or proteins apparently absent from normal serum.

In the past decade, however, it has become increasingly evident that anomalous protein components in serum or urine are not restricted to myelomatosis but occur in various other conditions. Such components have been the subject of many investigations, and it is the aim of this review to summarize current views on the nature and significance of these proteins.

\section{Occurrence of Anomalous Serum and Urinary Proteins}

For the present purpose, anomalous proteins are defined as those which appear as discrete abnormal components in the electrophoretic patterns obtained with conventional techniques, viz., boundary electrophoresis or zone electrophoresis on paper. A number of names, based either on the circumstances in which they are found or on their chemical properties, have been given to such proteins occurring in serum. Thus those found in myelomatosis are termed myeloma proteins, those with high molecular weights are termed macroglobulins, whilst those which precipitate on cooling are termed cryoglobulins. The use of such terms, however, tends to obscure the many affinities of these proteins. Anomalous urinary proteins comprise Bence Jones proteins.

Conditions in which anomalous proteins have been found fall into three groups, namely neoplastic disease, idiopathic haemolytic disease, and miscellaneous conditions.

Neoplastic Disease.-By far the commonest conditions associated with anomalous proteins are myelomatosis and lymphoma. About $80 \%$ of patients with myelomatosis have anomalous electrophoretic components in their sera ; a smaller proportion of cases excrete Bence Jones protein in the urine (for references see Owen and Rider, 1957). Lymphoma (using this as a generic term to include conditions designated more precisely lymphosarcoma, reticulum cell sarcoma, or Hodgkin's disease) is less frequently associated with anomalous serum components, although many instances have been recorded (e.g., Mackay, Taft, and Woods, 1957; Azar, Hill, and Osserman, 1957; Quattrin, Dini, and Piccoli, 1956 ; Mackay, 1959).* Bence Jones proteinuria also occurs in lymphoma, though it is less common than anomalous serum components (Mandema, van der Schaaf, and Huisman, 1955: Jim and Steinkamp, 1956; Mackay et al., 1957). Some patients with anomalous serum proteins present clinical and histological features intermediate between those of myelomatosis and malignant lymphoma (Mandema, 1954 ; Osserman and Gellhorn, 1955 ; Regniers, Wieme, Wunderly. and Burtin, 1956; Azar et al., 1957; Motulsky. Eriksen, Volwiler, and Donohue, 1958; Owen, Pitney, and O'Dea, 1959). Indeed the two conditions appear very closely related.

Occasionally, anomalous serum components have been recorded in lymphatic leukaemia (Rundles, Coonrad, and Arends, 1954), in \footnotetext{
*Some authors have rezarded lymphoma with anomalous serum
components as a condition distinct from lymphoma without such components as a condition distinct from lymphoma without such components, calling the former condition " macroglobulinaemia" (Waldenst-öm, 1944) on the grounds that the anomalous serum component is usually a macroglobulin. There would seem to be, matosis with myeloma serum proteins as distinct from myelomatosis without these proteins.
} 
monocytic leukaemia (Brown, Read, Wiseman, and France, 1948), and in chronic myeloid leukaemia (Brown et al., 1948). Such components have also been found in patients with myelofibrosis (Lucey, Leigh, Hoch, Marrack, Johns, Kekwick, and Holiday, 1950; Videbaek, 1955 ; Owen et al., 1959) though there was evidence in these cases of concomitant myelomatosis or lymphoma.

In a few instances anomalous serum components have been found in patients with malignant tumours in various sites (Schaub, 1953 ; Kanzow, 1954 ; Laurell, Laurell, and Waldenström, 1957; Waldenström, 1958 ; Kappeler, Krebs, and Riva, 1958 ; Owen et al., 1959). However, in some, but not all, of these cases there was evidence of a co-existing lymphoma. Bence Jones proteinuria has been found in cases of bronchial carcinoma (Copeland, 1931 ; Hughes, 1954).

Idiopathic Haemolytic Disease-Christenson and Dacie (1957) have noted the frequent association of anomalous serum electrophoretic components in patients with idiopathic haemolytic anaemia of the cold-agglutinin type, and similar cases have been reported by others (Sonnet, Louis, and Heremans, 1955; Fudenberg and Kunkel, 1957 ; Fudenberg, Barry, and Dameshek, 1958 : Owen et al., 1959). The association of anomalous serum components with haemolytic anaemia has also been found in patients with lymphoma (Craig, Waterhouse, and Young, 1952 ; Buffa and Rappaport, 1957 ; Christenson and Dacie, 1957). In contrast, anomalous serum components were not found in haemolytic anaemia of the warmagglutinin type (Christenson and Dacie, 1957 ; Charbonnier and Dausset, 1953).

Miscellaneous.-There are a few isolated reports of anomalous serum components in various other conditions. Of particular interest is the finding (Laurell et al., 1957) of such a component in the serum of a blood donor who showed no other physical or laboratory signs of disease. Other reports have concerned patients* with obscure anaemia (Flynn, 1954 ; Pitney, O'Sullivan, and Owen, 1958) ; hepatitis (Wieme, 1953); chronic urticaria (Motulsky et al., 1958); granulomatous lung disease (Motulsky et al., 1958); and cases in which a definite diagnosis was not established (Martin and Close, 1957 ; Laurell et al., 1957; Waldenström, 1958; Owen et al., 1959). To be included in this group are some

*It should be noted that in some of these cases the possibilit of coincidental neoplasia, e.g., of the reticulo-endothelial system, was not rigorously excluded. cases of " essential" cryoglobulinaemia (Hutchinson and Howell, 1953; Mackay, Eriksen, Motulsky, and Volwiler, 1956; Volpé, BruceRobertson, Fletcher, and Charles, 1956; Barnett, Curtain, and Hayes, 1956 ; Powers, 1958).

Apart from the above, a number of instances of minor electrophoretic anomalies of the same type have been described. These reports have concerned patients with nephritis (Stern, Mais, and Boggs, 1957), primary amyloidosis (Block, Rukavina, and Curtis, 1956), rheumatic disease (Wallis, 1950 ; McQueen, O'Shea, and Summerfield, 1954 ; Salt, 1956), tuberculosis (Matsui and Tamura, 1955), and viral hepatitis (Wajchenberg and Hoxter, 1955). However, others (for references see Owen, 1958a) who have studied the electrophoretic pattern in those conditions have failed to note such anomalies.

Very few systematic studies have been made to date on the anomalous components occurring in most of the conditions listed here under miscellaneous. Accordingly, the remainder of this review is restricted to consideration of the anomalous components associated with myelomatosis, malignant lymphoma, haemolytic disease and, from the miscellaneous group, essential cryoglobulinaemia.

\section{Anomalous Serum Proteins}

On electrophoresis, anomalous serum proteins behave as homogeneous proteins appearing on the electrophoretic pattern as narrow "spikes." The electrophoretic mobility of myeloma or lymphoma proteins varies from patient to patient : values obtained for a series of myeloma proteins showed a bimodal distribution, ranging from that of an $\alpha_{2}$ globulin to that of a slow $\gamma$ globulin (Putnam and Udin, 1953). Anomalous components associated with acquired haemolytic disease show less variation in electrophoretic mobility (Fudenberg and Kunkel, 1957); the majority migrate as fast $\gamma$ globulins. In essential cryoglobulinaemia the anomalous component has been found to migrate as either a fast or a slow $\gamma$ globulin.

In contrast, $\gamma$ globulin, which resembles anomalous serum components in many other respects, is electrophoretically heterogeneous. It contains a large number of individual proteins collectively with a range of electrophoretic mobilities and appears on the electrophoretic pattern as a broad hump. It is of interest. however, that the electrophoretic distribution of protein in normal serum precipitating with $\gamma$ globulin antiserum is much wider than that 
indicated by the hump on the electrophoretic pattern, approaching that shown collectively by anomalous serum components (Slater, 1955).

In occasional cases, two or more electrophoretically distinct anomalous components were present in the serum (Knedel, 1955; Neely and Neill, 1956 ; Owen, Rider, and Stewart, 1956 ; Petermann, Hamilton, and Korngold, 1956 ; Tsevrenis and Samios, 1958). Similar evidence has been obtained on electrophoresis of myeloma proteins in starch gel (Owen, Got, and Silberman, 1958).

On examination with the ultracentrifuge, some anomalous components behave as if homogeneous, whilst others show heterogeneity even though they appear homogeneous on electrophoresis. Such heterogeneity, however, usually amounts to the presence of a main component with much smaller amounts of other components. In myelomatosis, the main or only component usually has a molecular weight (as indicated by the sedimentation constant*) approximately that of the bulk of normal $\gamma$ globulin (sedimentation constant $\left.S_{*}^{29}=6-7 \mathrm{~S}\right)$. In contrast, the anomalous serum components in patients with lymphoma are commonly macroglobulins with higher molecular weights $\left(S_{\mathrm{w}}^{20}=11-28 \mathrm{~S}\right)$. However, these findings are not invariable. Thus, anomalous serum components with high sedimentation constants have been noted in patients with myelomatosis (Putnam and Udin, 1953 ; Smith, Brown, McFadden, Buettner-Janusch, and Jager, 1955; Motulsky et al., 1958 ; Wanner and Siebenmann, 1957 ; Curtain, 1959a) whilst components with low sedimentation constants have been found in patients in whom the histology was predominantly lymphoid in nature (Owen et al., 1959).

In idiopathic cold-agglutinin haemolytic disease the anomalous components are mostly macroglobulins (Christenson, Dacie, Croucher, and Charlwood, 1957 ; Fudenberg and Kunkel, 1957). In one such case, however, the amount of macroglobulin in the serum was within normal limits (Owen et al., 1959), i.e., less than $5 \%$ of the total protein (Svedberg and Pedersen, 1940). It may be noted that some of the macroglobulin normally in serum behaves as an $\alpha$ globulin while the remainder behaves as a $\gamma$ globulin (Wallenius, Trautman, Kunkel, and Franklin, 1957 ; Eriksen, 1958).

Deutsch and Morton (1957) have shown that certain anomalous macroglobulin components can be reversibly broken down under the action of

*The sedimentation constant of a protein expresses the rate at which its molecules travel in solution under centrifugal force. It forms an approximate measure of the molecular size of a protein. thiol reagents to smaller units (sedimentation constant $S_{\nabla}^{20}=6-7 \mathrm{~S}$ ). Similar results have been obtained with cold-agglutinin macroglobulins (Fudenberg and Kunkel, 1957). This suggests that the molecular size of an anomalous protein expresses the tendency of component units to aggregate and apparent heterogeneity on ultracentrifugation represents variable aggregation.

In amino-acid composition, myeloma and lymphoma proteins, though showing individual differences, closely resemble normal $\gamma$ globulin (Putnam, 1957, 1958). In only one instance has an amino-acid (hydroxy-proline) not detectable in $\gamma$ globulin been reported in an anomalous protein (Mandema et al., 1955). Anomalous serum proteins likewise resemble normal $\gamma$ globulin in their $\mathbf{N}$-terminal groups which are usually aspartyl or glutamyl or both. However, some myeloma proteins have been found to have either a leucyl or a phenylalanyl N-terminal grouping (Putnam, $1957,1958)$ neither of which has been detected in normal $\gamma$ globulin (Putnam, 1953 ; McFadden and Smith, 1953).

The use of carbohydrate stains after paper electrophoresis of serum has indicated that anomalous serum proteins contain carbohydrate (Rice, 1954 ; Sonnet et al., 1955). This has been confirmed by analysis of anomalous components isolated from serum, which have been found to contain hexose, hexosamine, and sialic acid (Lohss and Hillmann, 1953 ; Smith et al., 1955 ; MüllerEberhard and Kunkel, 1956). The carbohydrate content of components of low molecular weigh $\left(S_{\mathrm{w}}^{20}=6-7 \mathrm{~S}\right)$ is lower than that of components of high molecular weight $\left(\mathrm{S}_{\mathrm{w}}^{20}=11-28 \mathrm{~S}\right)$; in both groups, the components with the mobilities in the $\beta$ globulin range contain more carbohydrate than those with mobilities in the $\gamma$ globulin range (Müller-Eberhard and Kunkel, 1956; Laurell et al., 1957).

Normal $\gamma$ globulin likewise contains carbohydrate.' The main component $\left(S_{w}^{20}=7 \quad S\right)$ contains the same types of carbohydrate, in approximately the same amounts, as low molecular weight anomalous components with the mobilities in the $\gamma$ globulin range. Low molecular weight anomalous components with the mobilities in the $\beta$ globulin range contain more carbohydrate. The significance of this, however, is hard to assess since the appropriate fraction of normal proteins with which these faster components should be compared is uncertain (Müller-Eberhard and Kunkel, 1956). The heavy component of normal $\gamma$ globulin $\left(S_{*}^{20}=19 S\right)$ contains more carbohydrate than the main component and in this respect resembles anomalous macroglobulins. 
Sometimes the anomalous components in myelomatosis (Flemberg, 1948 ; Barr, Reader, and Wheeler, 1950 ; Putnam and Udin, 1953 ; Mackay et al., 1956), lymphoma (Waldenström, 1944; Lucey et al., 1950 ; Abrams, Cohen, and Meyer, 1949; Mackay et al., 1957), or idiopathic haemolytic disease (Christenson et al., 1957) are cryoglobulins, that is, they precipitate spontaneously from serum at temperatures of 0 to $10^{\circ}$ C. or higher. Likewise, as has been noted above, in some cases of essential cryoglobulinaemia, the cryoglobulin constitutes a discrete electrophoretic component.

The variable occurrence of small amounts of cold-insoluble protein in pooled normal plasma has been recorded by Morrison, Edsall, and Miller (1948). Cryoglobulins, usually in small amounts, i.e., less than $100 \mathrm{mg}$. $/ 100 \mathrm{ml}$, have also been found in serum in a variety of diseases, including leukaemia, rheumatoid arthritis, bacterial endocarditis, nephrosis, and kala azar (Holmberg and Grönwall, 1942 ; Wertheimer and Stein, 1944 ; Lerner, Barnum, and Watson, 1947 ; Dreyfuss and Librach, 1952). In some of these cases the isolated electrophoretic cryoglobulin was found to be electrophoretically homogeneous. In most, however, the amount was too small for the cryoglobulin to have appeared as a discrete electrophoretic component in the pattern obtained with whole serum.

Anomalous serum components in myelomatosis (Wuhrmann, Wunderly, and Hässig, 1950 ; Kunkel, Slater, and Good, 1951 ; Deutsch, Morton, and Kratochvil, 1956; Korngold and Lipari, 1956a) and in malignant lymphoma (Regniers et al., 1956 ; Korngold and van Leeuwen, 1957) have an antigenic structure related to that of $\gamma$ globulin, i.e., they have antigenic determinants* which are present also in $\gamma$ globulin. However, they do not have all the antigenic determinants in $\gamma$ globulin. Some lack more than others. There is also evidence that anomalous serum components contain patient-specific antigenic determinants (Habich, 1953 ; Slater, Ward, and Kunkel, 1955 ; Kanzow, Scholtan, and Müting, 1955 ; Korngold and van Leeuwen, 1957). Two distinct anomalous serum components with different antigenic structures have been observed in the same serum (Curtain, 1959a).

The question whether anomalous serum components contain antigenic determinants not present in normal $\gamma$ globulin or in any other serum protein is dealt with later.

\footnotetext{
* An antigenic determinant is that part of a protein molecule which immunologically stimulates the production of a single which immunologically stimulates the production of a single
antibody. One protein may have several antigenic determinants. Two proteins may have common antigenic determinants.
}

\section{Anomalous Urinary Components (Bence Jones} Proteins)

Unlike any of the serum proteins so far characterized, Bence Jones proteins usually precipitate on heating at temperatures below $60^{\circ}$ C. and redissolve, at least partially, on heating to $100^{\circ} \mathrm{C}$. Though presumably present in serum, they are most readily detected in urine, often being present there in large amounts.

With boundary electrophoresis or zone electrophoresis on paper, Bence Jones protein in urine usually appears as a single peak or zone. The electrophoretic mobility, however, varies from patient to patient. In some cases traces of other proteins are present as a result of renal damage (Owen, 1957). In occasional cases, the urinary electrophoretic pattern reveals the presence of two or more electrophoretic components (Putnam and Stelos, 1953 ; Berson and Yalow, 1957 ; Owen and Rider, 1958).

In some instances, one of the components appears to be an anomalous serum component which has escaped from the circulation (Owen, 1957). In others the Bence Jones protein appears to comprise more than one electrophoretic component. Electrophoresis in starch-gel has similarly shown electrophoretic heterogeneity in some Bence Jones proteins (Engle, Woods, and Pert, 1957 ; Flynn and Stow, 1958).

Bence Jones proteins have usually a smaller molecular size than do most serum proteins which presumably allows their ready escape from the circulation into the urine. The sedimentation constant varies from case to case though most lie in the range $\mathrm{S}_{\mathrm{w}}^{20}=2.5-4.5 \mathrm{~S}$ (Rundles, Cooper, and Willett, 1951 ; Putnam and Stelos, 1953). They show marked individual differences in amino-acid composition (Putnam, 1957). Thus methionine has been reported to be lacking in some Bence Jones proteins (Dent and Rose, 1949 ; Polonovski, Delbarre, and Lévy, 1954) though present in others (Ågren, 1952; Deutsch, 1955).

Like anomalous serum components, Bence Jones proteins are antigenically related to normal $\gamma$ glob alin (Korngold and Lipari, 1956b ; Deutsch, Kratochvil, and Reif, 1955; Burtin, Hartmann, Fauvert, and Grabar, 1956). However, they too lack some of the antigenic determinants of normal $\gamma$ globulin.

As might be expected from these findings, Bence Jones proteins and anomalous serum components contain common antigenic determinants. Bence Jones proteins with different antigenic structures have been found in the same urine (Hektoen and Welker, 1940). 


\section{Formation and Fate of Anomalous Components}

The frequent occurrence of anomalous serum and urinary protein components in myelomatosis and malignant lymphoma has led to the hypothesis, first put forward in respect of myelomatosis (Magnus-Levy, 1933), that anomalous components are formed by myeloma or lymphoma cells. More direct evidence of the presence of anomalous components in myeloma or lymphoma tumour tissues has been obtained by several workers (Martin, 1947 ; Abrams et al., 1949 ; Lane, 1952 ; Miller, Brown, Miller, and Eitelman, 1952 ; Buffa and Rappaport, 1957). Protein antigenically similar to (and probably identical with) the anomalous serum component has been demonstrated within myeloma cells by means of fluorescent antibody stains (Wollensak and Seybold, 1956 ; Vazquez, 1958 ; Curtain, 1959a). Further, isotope incorporation studies have shown that myeloma cells are able to synthesize the anomalous components (Sonnet, 1957 ; Meyer, 1957). Supporting evidence comes from the discovery in mice of a transmissible plasmacytoma which is associated with an anomalous serum component (Potter, Fahey, and Pilgrim, 1957). Whilst these findings shed light on the pathogenesis of anomalous components in patients with neoplastic conditions, they do not, of course, indicate the source of anomalous proteins in other conditions.

Labelling of anomalous serum proteins in myelomatosis with isotopes has shown that these components have a dynamic existence with halflives similar to those of other serum proteins (Hardy and Putnam, 1955 ; Putnam, Meyer, and Miyake, 1956; Osserman, Graff, Marshall, Lawlor, and Graff, 1957 ; Berson and Yalow, 1957). Their exact fate, however, is unknown. Serial studies indicate that the concentration of an anomalous component in serum is frequently more or less constant over long periods in spite of the progression of the disease (Owen, Rider, and Newall, 1957). Repeated venesections have likewise failed to influence the plasma level significantly (Barr et al., 1950; Soulier, 1950). This suggests that the production and/or destruction mechanism is regulated by the concentration in the plasma. Individual differences in the amount of the anomalous component in plasma imply a different "setting" of the regulating mechanism in each case.

Reiner and Stern (1953) have noted apparent changes in the electrophoretic mob:lity of myeloma proteins in serum during the course of the disease. However, these were slight and may possibly have been due to changes in the composition of the sample analysed rather than to change in the true mobility of the myeloma protein.

It has been suggested that Bence Jones proteins may represent breakdown fragments of normal or anomalous serum components (Rundles et al., 1951 ; Osserman and Lawlor, 1955). However, isotopic studies (Hardy and Putnam, 1955; Putnam et al., 1956) indicate that this is unlikely. Moreover, in individual cases, Bence Jones protein and anomalous serum protein are present or absent independently. Data obtained from isotopic studies are, however, consistent with the hypothesis that Bence Jones proteins are precursors of normal or anomalous serum components (Putnam, 1957).

\section{Are the Anomalous Components Normally Produced in Small Amounts?}

An answer to this question has been sought by two main routes.

(1) The Chemical Approach.-The aim with this approach has been to determine whether or not the anomalous component has some characteristic, e.g., amino acid, end-grouping, molecular size, not present in any of the normal components of serum. It has been claimed that hydroxyproline was present in an anomalous component though absent from normal serum proteins (Mandema et al., 1955). Clearly, however, failure to detect a protein with a particular feature in normal serum is of little significance since it is always possible that a more sensitive technique will succeed in this (Martin and Close, 1957).

Most comparative studies have failed to reveal any feature peculiar to anomalous components. Moreover, there has been a tendency in such studies to compare anomalous components with $\gamma$ globulin or fractions thereof, on the grounds that they resemble $\gamma$ globulin in other respects, rather than with the proteins of whole serum or, better, plasma.

(2) The Immunological Approach.-The aim with this approach has been to determine whether or not the anomalous component has some immunological characteristic not present in the normal components of plasma. Such studies* fall into two groups: (1) An antiserum is prepared against the purified anomalous protein: this is allowed to react with whole human plasma and the antiserum is then tested for activity against the antigen. If none remains it is concluded that

* Since antigenic specificity presumably stems from molecular configurations, these studies constitute, strictly, part of a " chemical approach" However they are more conveniently considered separately. 
the anomalous component is present in normal plasma.

So far those who have investigated this particular aspect have failed to reach agreement. Some have concluded that myeloma proteins (Wuhrmann et al., 1950; Lohss and Hillmann, 1953 ; Lohss, Weiler, and Hillmann, 1953 ; Korngold and Lipari, 1956a) and lymphoma proteins (Boerma and Mandema, 1957 ; Korngold and van Leeuwen, 1957 ; Scheidegger, Weber, and Hässig, 1958) contain antigenic determinants absent from normal serums whilst others (Deutsch et al., 1956 Smith et al., 1955 ; Morton and Deutsch, 1958) have concluded to the contrary. Patient-specific antigenic reactions of anomalous components suggest the view that anomalous components are abnormal. It is possible, however, that there are person-specific components in normal plasma.

However, even if all the antibody activity can be absorbed with normal plasma there remains the possibility that the proteins in plasma may contain all the antigenic determinants present in the anomalous component though not necessarily all in the same molecular species. On this view, the anomalous component would be, antigenically, a hybrid of two or more normal proteins (Curtain, 1959b).

(2) Immunological tolerance to the proteins of normal plasma is produced in a rabbit by neonatal injection. Subsequently the animal is challenged with the anomalous component and the animal's serum examined for antibody to the anomalous component (Curtain, 1959b).

Results of such experiments have suggested (Curtain, 1959b) that all the antigenic determinants of anomalous components are normally present in plasma. However, the possibility that the anomalous components are hybrids, and thus abnormal, is not excluded.

\section{Pathogenesis of Anomalous Components}

The mechanisms which have been suggested to account for the production of anomalous components can be set out as follows:

(1) They are formed by proliferating (malignant) cells which are of a type normally producing the anomalous component but are normally present in such small numbers that the anomalous component remains undetectable.

(2) They are formed by proliferating (malignant) cells, progeny of a type which does not normally produce anomalous components, but which start to produce these components as a result of some pathological change.
(3) They are formed by cells which are normally present and which either form normally only insignificant amounts of anomalous components or form them only as a result of some stimulus.

The first possibility amounts to neoplasia of a cell active in the synthesis of protein. Evidence indicating that myeloma or lymphoma cells form anomalous components has already been put forward. The condition would thus be analogous to various "biochemically active" tumours such as the carcinoid tumour, the islet-cell adenoma, or the pituitary adenoma. The variable chemical nature of the anomalous components, however, would mean that there are normally present in the body a great number of cells (presumably of the reticulo-endothelial tissue) each forming a different protein which only becomes detectable when the particular line of cells producing it proliferates extensively. This mechanism is analogous to the clonal selection mechanism developed by Burnet (1957) to account for the production of antibodies. It should be noted, however, that individual antibodies in serum are widely distributed in the electrophoretic spectrum (Loveless and Cann, 1953 ; Laurell, 1955 ; Skom and Talmage, 1958), unlike anomalous components which are mostly electrophoretically homogeneous.

Accordingly, each anomalous protein could be a component of $\gamma$ globulin which is recognized to comprise a large number of molecular species (Saifer and Corey, 1956). This would account for the physico-chemical affinities of $\gamma$ globulin and anomalous serum components. Moreover, there is evidence (Bing, 1940 ; Fagraeus, 1948 ; Coons, Leduc, and Connolly, 1955 ; Good, 1955 ; Ortega and Mellors, 1957) that $\gamma$ globulin is synthesized largely by plasma and lymphoid cells which are, at least morphologically, related to myeloma and lymphoma cells respectively. The selective proliferation of a single cell line required by this hypothesis and the consequent production of detectable amounts of a single protein is to be contrasted with the presumably non-selective proliferation of reticulo-endothelial cells, e.g., plasma cells, occurring in other conditions such as rheumatoid arthritis (Hayhoe and Smith, 1951), infection (Fadem and McBirnie, 1950), or neoplasia (Coste, Bourgeois, Delbarre, and Blatrix, 1948 ; Clark and Muirhead, 1954). In these conditions there is usually no anomalous serum component though often a generalized hyperglobulinaemia.

The second possibility would involve somatic mutation and offers an alternative explanation for the apparently unlimited variation in the chemical and immunological nature of individual anomalous 
components. In considering the possibility that neoplasia represents the outcome of somatic mutation, Armitage and Doll (1954) have concluded that a series of changes must occur before the cell becomes frankly malignant. It is possible that occasionally one such change might cause the cell to produce the anomalous component (Mackay, 1956). This would explain the variable occurrence of anomalous components in patients suffering from the same disease, e.g., myelomatosis.

If this is correct, it would appear that this mutation usually occurs before that inducing frank malignancy, since the first appearance of anomalous serum components after the disease has become established has only rarely been recorded (Owen et al., 1957 ; see, however, Rundles et al., 1951 ; Martin and Close, 1957). On the other hand, a change inducing the formation of an anomalous component could only become evident if sufficient cells of that particular line were present. This would occur when cell division became malignant. Possibly more benign cell division would result in the production of sufficient cells to form detectable amounts of anomalous components without producing anatomical evidence of neoplasia (cf. Case 2, Martin and Close, 1957). This would explain apparently idiopathic cases, e.g., "essential" cryoglobulinaemia.

The possibility that anomalous components were the manifestation of virus infection was considered by Waldenström (1944) and also by Dent and Rose (1949), who pointed out that certain Bence Jones proteins are similar chemically to the protein of tobacco mosaic virus in that they usually lack methionine. However, some Bence Jones proteins contain methionine. Moreover, evidence that myelomatosis or lymphoma is an infective condition has yet to be obtained.

Curtain (1959a), studying a case of myelomatosis in which the serum contained two immunologically distinct myeloma proteins, obtained evidence that they were not formed in the same cell. If this is true of all cases in which two (or more) distinct components are present, it would be necessary according to either the first or the second possibility to postulate selective proliferation of two cell lines (or more), each producing a different protein. This postulate would also be necessary to account for the production of Bence Jones proteins, when these accompany anomalous serum components, unless both proteins are formed in the same cell, a possibility which does not appear to have been investigated.

The mutation theory would apnear to offer the most ready solution to this difficulty, on the grounds that the cells from which the two mutated 을 cell lines arose had already undergone a mutation $\vec{\Rightarrow}$ (or mutations) which made all progeny regardless $\stackrel{9}{\stackrel{9}{+}}$ of subsequent mutations prone to become malignant. However, it should be remembered $\frac{\overline{ }}{2}$ that apparent molecular differences in anomalous $\frac{\bar{s}}{7}$ components may result from physical phenomena $\stackrel{\mathbb{Q}}{\Omega}$ such as molecular aggregation. Observations in this direction have already been reported (Wiedermann, 1958).

Whilst either of the first two possibilities $\overrightarrow{\vec{\omega}}$ provides an explanation for the association of $\stackrel{\sigma}{S}$ anomalous components with neoplasia of the reticulo-endothelial system or elsewhere, the third $\vec{\omega}$ possibility seems necessary to account for cases in which neoplasia are absent. The nature of the in stimulus which would cause cells to increase the production of a protein to a detectable level or to produce a protein de novo is conjectural. The $\vec{c}$ problem is similar to that posed by the production of antibodies.

In cases in which idiopathic cold-agglutinin haemolytic disease is associated with anomalous $\overrightarrow{0}$ serum components the latter have been shown to 8 have anti-erythrocytic properties. It seems likely, however, that their anti-erythrocytic activity is fortuitous and that the condition is not primarily one of auto-immunization. The concentration of anomalous components in serum is often much higher (g./100 ml.) than that usually assigned to $\triangle$ antibodies. Further, the agglutinating properties $\overrightarrow{\vec{O}}$ of such proteins are greatest at non-physiological $\exists$ temperatures and they show little specificity towards the source of the erythrocytes whether from different individuals or different species (Dacie, 1954). This is in contrast to the behaviour of warm agglutinins (Dacie and Cutbush, 1954). As has been pointed out (Owen et al., 1959), in Hashimoto's disease, which is much more certainly an auto-immune phenomenon, the serum contains auto-immune antibodies (Witebsky, Rose, and Shulman, 1958 ; Roitt, Doniach, Campbell, and Hudson, 1956), yet the serum electrophoretic pattern does not contain anomalous components, $\mathcal{\sigma}$ though the $\gamma$ globulin peak is often increased $N$ (Cooke and Luxton, 1955; Doniach and Hudson, N 1957). The agglutinating activity of certain $\omega$ anomalous components is possibly analogous to the action of certain plant proteins in agglutinating $\stackrel{O}{=}$ erythrocytes (Landsteiner, 1936), though some of $\Phi_{2}$ the latter proteins, unlike anomalous serum? components, show specificity towards erythrocytes of different ABO blood groups (Renkonen, 1948).

It is of interest that the anti-erythrocytic $\frac{O}{\mathbb{D}}$ activity of certain anomalous (macroglobulin) $\stackrel{\unrhd}{\varnothing}$ components disappears on dissociation of the 
molecule into smaller units (Fudenberg and Kunkel, 1957). However, as these authors point out, the anti-erythrocytic activity is not simply due to the size of the molecule since most anomalous macroglobulin components do not have this property.

Lastly, the possibility that anomalous components, in some instances, constitute a congenital anomaly deserves consideration. Hereditary differences in the protein composition of serum have been revealed by starch-gel electrophoresis (Smithies, 1955, 1958). This could explain the presence of such components in the serum of apparently normal persons or of persons suffering from a disease not usually associated with anomalous components.

\section{Pathological Effects}

In patients with anomalous components, certain effects can be attributed to the production of anomalous components and to their presence in serum rather than to any primary disease process which may be present. These effects fall into two groups, those due to the consumption of materials in the synthesis of these components and those which are a direct consequence of the presence of the components in plasma.

The continued synthesis of anomalous components must involve utilization of amino-acids in competition with other tissues. Further, the urinary excretion of such components, e.g., Bence Jones proteins, involves loss of nitrogen from the body. Daily excretion rates of Bence Jones protein as high as $30 \mathrm{~g}$. have been recorded (Hopkins and Savory, 1911 ; Dent and Rose, 1949).

It should be noted, however, that whilst cachexia is common in the conditions in which anomalous components occur, e.g., myelomatosis, lymphoma, it is also prominent in other neop!astic conditions. Further comparison of mean survival times of patients with and without Bence Jones proteinuria have failed to reveal that this loss of nitrogen has a significant effect on survival time (Owen, 1958b). Similarly, no difference has been found in the mean survival times of patients with severe hyperglobulinaemia and those with only moderate hyperglobulinaemia (Owen, 1958).

A reduced amount of normal $\gamma$ globulin has frequently been noted in patients with anomalous serum components (Adams, Alling, and Lawrence, 1949 ; Rundles et al., 1951 ; Snapper, Turner, and Moscovitz, 1953 ; Waldenström, 1954 ; Zinneman and Hall, 1954 ; Lawson, Stuart, Paull, Phillips, and Phillips, 1955; Porges, 1956; Firkin and Blackburn, 1958; Owen et al., 1959), and this finding is probably more common than such reports indicate, since the anomalous component frequently migrates as a $\gamma$ globulin, thus obscuring any diminution in normal $\gamma$ globulin. Hypogammaglobulinaemia in such patients may reflect a competition for raw materials between cells forming normal $\gamma$ globulin and those forming an anomalous component, especially in view of the chemical similarities of anomalous components and normal $\gamma$ globulin. However, other factors are almost certainly involved. Thus hypogammaglobulinaemia has been observed in patients with myelomatosis, lymphoma, or leukaemia (Arends, Coonrad, and Rundles, 1954 ; Jim and Reinhard, 1956; Wall, 1956 ; Citron, 1957) in whom anomalous serum or urinary components were not present. This might suggest that competition is for space rather than for raw materials. On the other hand, many patients with lymphoma or leukaemia have normal or even increased serum $\gamma$ globulin levels (Rundles et al., 1951 ; Jim and Reinhard, 1956 ; Owen et al., 1956).

The occurrence of a haemorrhagic tendency, manifested as bruising, bleeding from mucosal surfaces, or haemorrhagic retinitis, in association with anomalous serum components is well documented (Waldenström, 1944 ; Craddock, Adams, and Figueroa, 1953 ; Frick, 1955 ; Long, Riopelle, Francoeur, Pare, Poirier, Georgesco, and Colpron, 1955 ; Jim and Steinkamp, 1956). This has been attributed either to a defective coagulation mechanism or to an effect of the anomalous serum components on capillary permeability (Waldenström, 1952). Direct interaction of anomalous components with coagulation factors has been demonstrated in some cases (Henstell and Feinstein, 1957 ; Firkin, 1958). Thrombocytopenia, however, is often present, and is presumably a contributory factor (Frick, 1955; Jim and Steinkamp, 1956; Mackay, 1956).

Cardiac failure in such patients has been attributed to a high blood viscosity resulting from the presence of anomalous components in plasma (Barr et al., 1950 ; McFarlane, Dovey, Slack, and Papastamatis, 1952). A thrombotic tendency which, in some cases, may paradoxically accompany a haemorrhagic tendency, has also been attributed to a high blood viscosity (Frick, 1955) and is partly responsible for the retinitis present in some cases. Thrombosis of intracranial vessels is presumably also responsible in part for neurological and psychological symptoms, though there may be infiltration with neoplastic cells (Mackay, 1956). Where the anomalous component 
is a cryoglobulin, blood viscosity may be greatly increased in exposed areas as a result of intravascular gellification or precipitation of the cryoglobulin. Local circulatory failure consequent on this gives rise to Raynaud's phenomenon and peripheral gangrene.

An increased erythrocyte sedimentation rate is usual, though not invariable (Owen and Rider, 1957), in patients with anomalous serum components. Presumably the high sedimentation rate is due to interaction between anomalous components and erythrocytes.

Renal failure in myelomatosis is attributable to the deposition of protein within the kidney (Snapper et al., 1953; Allen, 1951). Rarely protein as para-amyloid is deposited in the glomeruli. More commonly protein accumulates within the tubules. There is, however, little correlation between the degree of hyperglobulinaemia or proteinuria and the extent of renal impairment (Allen, 1951). Amino-aciduria occurring in myelomatosis (Engle, 1956; Sirota and Hamerman, 1954) is perhaps due to direct competition between the tubular absorption of amino-acids and of anomalous components, especially Bence Jones proteins which presumably escape from the plasma more readily than anomalous serum components.

False positive Wassermann reactions have been noted in certain sera containing anomalous components (Long et al., 1955 ; Martin and Close, 1957; Zlotnick, 1958) whilst a related reaction (AICF) has been observed in other cases (Mackay and Gajdusek, 1958 ; Mackay, 1959). Some sera with anomalous components have proved anticomplementary (Snapper et al., 1953 ; Volpé et al., 1956). It is not known, however, whether these reactions with complement are attributable directly to the presence of the anomalous component or, indirectly, to the underlying disease process.

\section{Conclusions}

Anomalous serum and urinary components occur most commonly in myelomatosis and lymphoma. They also occur occasionally in a number of other conditions. In a few cases, no histological evidence of disease can be obtained which suggests that such proteins are manifestations of a primary lesion at a biochemical level. Certain morphological changes are probably secondary to the presence of the anomalous components.

In some of the conditions in which they have been found, incomplete data concerning occur- rence of anomalous components make it yet impossible to assess their significance. In cases associated with malignant cell division, however, the production of anomalous components can best be attributed either to the selective proliferation of normal cells, i.e., cells which normally form the anomalous component in small amounts, or to the selective proliferation of abnormal cells, i.e., cells which have undergone a somatic mutation conferring on them the ability to produce the anomalous component.

The choice between these two possibilities depends largely on whether anomalous components are qualitatively normal or abnormal. As yet evidence does not allow a clear decision on this issue. Indeed, whilst it may be possible to prove that anomalous components are normally present in small amounts it is virtually impossible to prove that they are not.

We should like to thank all those with whom we have discussed various aspects of this review for their helpful criticism. We are also indebted to the National Health and Medical Research Council of Australia for a grant towards the cost of investigations described herein.

\section{REFERENCES}

Abrams, A., Cohen, P. P., and Meyer, O. O. (1949). J. biol. Chem., $181,237$.

Adams, W. S., Alling, E. L., and Lawrence, J. S. (1949). Amer. J. Med., 6, 141.

Åren, G. (1952). Acta chem. scand., 6, 1232.

Allen, A. C. (1951). The Kidney: Medical and Surgical Diseases. Grune and Stratton, New York.

Arends, T., Coonrad, E. V., and Rundles, R. W. (1954). Amer. J. Med., 16, 833.

Armitage, P., and Doll, R. (1954). Brit. J. Cancer, 8, 1.

Azar, H. A., Hill, W. T., and Osserman, E. F. (1957). Amer. J. Med., 23, 239.

Barnett, A. J., Curtain, C. C., and Hayes, R. A. (1956). Aust. Ann. Med., $5,177$.

Barr, D. P., Reader, G. G., and Wheeler, C. H. (1950). Ann. intern. Med., 32, 6.

Berson, S. A., and Yalow, R. S. (1957). J. Lab. clin. Med., 49, 386

Bing, J. (1940). Acta med. scand., 103, 547.

Block, W. D., Rukavina, J. G., and Curtis, A. C. (1956). J. Lab. clin. Med., 47, 357.

Boerma, F. W., and Mandema, E. (1957). Ibid., 49, 358.

Brown, R. K., Read, J. T., Wiseman, B. K., and France, W. G. (1948). Ibid., 33, 1523 .

Buffa, F., and Rappaport, H. (1957). Amer. J. Med., 22, 504.

Burnet, F. M. (1957). Aust. J. Sci., $20,67$.

Burtin, P., Hartmann, L., Fauvert, R., and Grabar, P. (1956). Rev. franc. Et. clin. biol., i, 17.

Charbonnier, A., and Dausset, J. (1953). Ann. Biol. clin., 11, 22.

Christenson, W. N., and Dacie, J. V. (1957). Brit. J. Haemat., 3, 153. Croucher, B. E. E., and Charlwood, P. A. (1957). Ibid. $3,262$.

Citron, K. M. (1957). Brit. med. J., 1, 1148.

Clark,

Cooke, R. T., and Luxton, R. W. (1955). Lancet, 1, 968.

Coons, A. H., Leduc, E. H., and Connolly, J. M. (1955). J. exp. Med., $102,53$.

Copeland, M. M. (1931). Arch. Surg. (Chicago), 23, 581.

Coste, F., Bourgeois, P., Delbarre, F., and Blatrix, C. (1948). Bull. Soc. méd. Hôp. Paris, 64, 364.

Craddock, C. G., Adams, W. S., and Figueroa, W. G. (1953). J. Lab. clin. Med., 42, 847. 
Craig, A. B., Waterhouse, C., and Young, L. E. (1952). Amer. J. Med., 13, 793 .

Curtain, C. C. (1959a). Aust. Ann. Med., 8, 143.

(1959b). Brit. J. exp. Path., 40, 255.

Dacie, J. V. (1954). The Haemolytic Anaemias. Churchill, London. and Cutbush, M. (1954). J. clin. Path., 7, 18.

Dent, C. E., and Rose, G. A. (1949). Biochem. J., 44, 610.

Deutsch, H. F. (1955). J. biol. Chem., 216, 97.

- Kratochvil, C. H., and Reif, A. E. (1955). Ibid., 216, 103. and Morton, J. I. (1957). Science, 125, 600.

- and Kratochvil, C. H. (1956). J. biol. Chem., $222,39$.

Doniach, D., and Hudson, R. V. (1957). Brit. med. J., 1, 672.

Dreyfuss, F., and Librach, G. (1952). J. Lab. clin. Med., 40, 489.

Ellinger, A. (1899). Dtsch. Arch. klin. Med., 62, 254.

Engle, R. L., Jr. (1956). J. Mt Sinai Hosp., 23, 193.

W Woods, K. R., and Pert, J. H. (1957). J. clin. Invest., 36, 888.

Eriksen, N. (1958). J. Lab. clin. Med., 51, 521.

Fadem, R. S., and McBirnie, J. E. (1950). Blood, 5, 191.

Fagraeus, A. (1948). Acta med. scand., 130, Suppl. 204.

Firkin, B. G. (1958). Amer. J. Med., 24, 974.

— and Blackburn, C. R. B. (1958). Quart. J. Med., $27,187$.

Flemberg, T. (1948). Nord. Med., 37, 330.

Flynn, F. V. (1954). Proc. roy. Soc. Med., 47, 827.

and Stow, E. A. (1958). J. clin. Path., 11, 334.

Frick, P. G. (1955). Amer. J. clin. Path., 25, 1263.

Fudenberg, H., Barry, I., and Dameshek, W. (1958). Blood, 13, 201.

- and Kunkel, H. G. (1957). J. exp. Med., 106, 689.

Good, R. A. (1955). J. Lab. clin. Med., 46, 167.

Habich, H. (1953). Schweiz. med. Wschr., 83, 1253.

Hardy, S., and Putnam, F. W. (1955). J. biol. Chem., 212, 371.

Hayhoe, F. G. J., and Smith, D. R. (1951). J. clin. Path., 4, 47

Hektoen, I., and Welker, W. H. (1940). Biochem. J., 34, 487.

Henstell, H. H., and Feinstein, M. (1957). Amer. J. Med., 22, 381.

Holmberg, C. G., and Grönwall, L. (1942). Hoppe-Seyl. Z. physiol. Chem., 273, 199

Hopkins, F. G., and Savory, H. (1911). J. Physiol. (Lond.), 42, 189.

Hughes, J. T. (1954). Brit. med. J., 2, 1267.

Hutchinson, J. H., and Howell, R. A. (1953). Ann. intern. Med., 39, 350.

Jim, R. T. S., and Reinhard, E. H. (1956). Ibid., 44, 790. and Steinkamp, R. C. (1956). J. Lab. clin. Med., 47, 540.

Jones, H. Bence (1848). Phil. Trans. B., 138, pt. 1, p. 55.

Kanzow, U. (1954). Klin. Wschr., 32, 154.

- Scholtan, W., and Müting, A. (1955). Ibid., 33, 1043.

Kappeler, R., Krebs, A., and Riva, G. (1958). Helv. med. Acta, 25,

Knedel, M. (1955). Cited by Grassmann, W. (1956). In Ciba Foundation Symposium on Paper Electrophoresis, p. 2. Churchill, London.

Korngold, L., and Lipari, R. (1956a). Cancer, 9, 183. (1956b). Ibid., 9, 262 and van Leeuwen, G. (1957). J. exp. Med., 106, 477.

Kunkel, H. G., Slater, R. J., and Good, R. A. (1951). Proc. Soc. exp. Biol. (N.Y.), 76, 190. Landsteiner, K. (1936). Specificity of Serological Reactions. Thomas,
Springfield, Illinois.

Lane, S. L. (1952). Oral Surg., 5, 434.

Laurell, A.-B. (1955). Acta path. microbiol. scand., Suppl. 103.

Laurell, C.-B., Laurell, H., and Waldenström, J. (1957). Amer.J. Med., 22, 24.

Lawson, H. A., Stuart, C. A., Paull, A. M., Phillips, A. M., and Phillips, R. W. (1955). New Engl. J. Med., 252, 13.

Lerner, A. B., Barnum, C. P., and Watson, C. J. (1947). Amer. J. med. Sci., 214, 416

Lohss, F., and Hillmann, G. (1953). Z. Naturf., 8b, 706.

Weiler, E., and Hillmann, G. (1953). Ibid., 8b, 625

Long, L. A., Riopelle, J. L., Francoeur, M., Pare, A., Poirier, P., Georgesco, M., and Colpron, G. (1955). Canad. med. Ass. J., 73, 726 .

Loveless, M. H., and Cann, J. R. (1953). Science, 117, 105

Lucey, H. C., Leigh, E., Hoch, H., Marrack, J. R., Johns, R. G. S., Kekwick, R. A., and Holiday, E. R. (1950). Brit. J. exp. Path., 31, 380.

McFadden, M. L., and Smith, E. L. (1953). J. Amer. chem. Soc. 75,2784 McFarlane, A.S., Dovey, A., Slack, H. G. B., and Papastamatis, S. C.
(1952). J. Path. Bact., 64, 335.

Mackay, I. R. (1956). Aust. Ann. Med., 5, 244.

(1959). Ibid., 8, 158.

Eriksen, N., Motulsky, A. G., and Volwiler, W. (1956). Amer. J. Mackay, I. R., and Gajdusek, D. C. (1958). Arch. intern. Med.,
101, 30.

- Taft, L. I., and Woods, E. F. (1957). Brit. med. J., 1, 561

McQueen, E. G., O'Shea, R. F., and Summerfield, M. P. (1954). Aust. Ann. Med., 3, 270 .

Magnus-Levy, A. (1933). Z. klin. Med., 126, 62.

Mandema, E. (1954). Ned. T. Geneesk., 98, 2109.

van der Schaaf, P. C., and Huisman, T. H. J. (1955). J. Lab. clin. Med., 45, 261.

Martin, N. H. (1947). J. clin. Invest., 26, 1189.

- and Close, H. G. (1957). Lancet, 2, 8.

Matsui, K., and Tamura, S. (1955). Kekkaku, 30, 563, as cited by Chem. Abstr. (1956), 50, 2030a.

Meyer, F. (1957). Fed. Proc., 16, 222

Miller, G. L., Brown, C. E., Miller, E. E., and Eitelman, E. S. (1952). Cancer Res., 12, 716.

Morrison, P. R., Edsall, J. T., and Miller, S. G. (1948). J. Amer. chem. Soc., 70,3103 .

Morton, J. I., and Deutsch, H. F. (1958). J. biol. Chem., 231, 1119.

Motulsky, A. G., Eriksen, N., Volwiler, W., and Donohue, D. (1958). Trans. 6th Congr. Europ. Soc. Haemat., Copenhagen, 1957. Part 2, p. 150. Karger, Basel.

Müller-Eberhard, H. J., and Kunkel, H. G. (1956). J. exp. Med., $104,253$.

Neely, R. A., and Neill, D. W. (1956). Brit. J. Haemat., $2,32$.

Ortega, L. G., and Mellors, R. C. (1957). J. exp. Med., 106, 627.

Osserman, E. F., and Gellhorn, A. (1955). Proc. Amer. Ass. Cancer Res., 2, 38.

- Graff, A., Marshall, M., Lawlor, D., and Graff, S. (1957). J. clin. Invest., 36, 352.

- and Lawlor, D. P. (1955). Amer. J. Med., 18, 462.

Owen, J. A. (1957). Lancet, 2, 1286.

(1958a). Advanc. Clin. Chem., 1, 237.

(1958b). Unpublished data.

Got, C., and Silberman, H. J. (1958). Clin. Chim. Acta, 3, 605.

Pitney, W. R., and O'Dea, J. F. (1959). J. clin. Path., 12, 344. and Rider, W. D. (1957). Ibid., 10, 373.

(1958). Blood, 13, 475 .

and Newall, J. (1957). Clin. Chim. Acta, 2, 522

and Stewart, C. P. (1956). 4de Colloq., Sint. Jans Hospital, Brugge, p. 103.

Petermann, M. L., Hamilton, M. G., and Korngold, L. (1956). Cancer, 9, 193.

Pitney, W. R., O'Sullivan, W. J., and Owen, J. A. (1958). Brit. med. J., 2, 1508.

Polonovski, M., Delbarre, R., and Lévy, G. (1954). Bull. Soc. Chim. biol. (Paris), 36, 1273 .

Porges, R. F. (1956). J. Lab. clin. Med., 47, 960.

Potter, M., Fahey, J. L., and Pilgrim, H. I. (1957). Proc. Soc. exp. Biol. (N.Y.), 94, 327

Powers, J. H. (1958). Amer. J. clin. Path., 30, 58

Putnam, F. W. (1953). J. Amer. chem. Soc., 75, 2785.

- (1957). Physiol. Rev., 37, 512.

(1958). J. biol. Chem., 233, 1448.

Meyer, F., and Miyake, A. (1956). Ibid., 221, 517.

and Stelos, P. (1953). Ibid., 203, 347.

and Udin, B. (1953). Ibid., 202, 727. Quattrin, N., Dini, E., and Piccoli, P. (1956). Acta med. scand., 156,
25.

Regniers, P., Wieme, R. J., Wunderly, C., and Burtin, P. (1956). Schweiz. med. Wschr., 86, 1140.

Reiner, M., and Stern, K. G. (1953). Acta haemat. (Basel), 9, 19.

Renkonen, K. O. (1948). Ann. Med. exp. Fenn., 26, 66.

Rice, W. G. (1954). J. Lab. clin. Med., 44, 544.

Roitt, I. M., Doniach, D., Campbell, P. N., and Hudson, R. V. (1956). 'Lancet, 2, 82i.

Rundles, R. W., Coonrad, E. V., and Arends, T. (1954). Amer. J. Med., 16, 842 . Cooper, G. R., and Willett, R. W. (1951). J. clin. Invest., 30 ,

Saifer, A., and Corey, H. (1956). J. biol. Chem., 222, 803.

Salt, H. B. (1956). Clin. Chem., 2, 35.

Schaub, F. (1953). Schweiz. med. Wschr., 83, 1256.

Scheidegger, J. J., Weber, R., and Hässig, A. (1958). Helv. med. Acta, 25, 25.

Sirota, J. H., and Hamerman, D. (1954). Amer. J. Med., 16, 138.

Skom, J. H., and Talmage, D. W. (1958). J. clin. Invest., 37, 783.

Slater, R. J. (1955). Arch. Biochim. Biophys., 59, 33.

— Ward, S. M., and Kunkel, H. G. (1955). J. exp. Med., 101, 85. 
Smith, E. L., Brown, D. M., McFadden, M. L., Buettner-Janusch, V., and Jager, B. V. (1955). J. biol. Chem., 216, 601.

Smithies, O. (1955). Biochem. J., 61, 629.

(1958). Nature (Lond.), 181, 1203.

Snapper, I., Turner, B., and Moscovitz, H. L. (1953). Multiple Myeloma. Grune \& Stratton, New York.

Sonnet, J. (1957). Scand. J. clin. Lab. Invest., 10, Suppl. 31, p. 309.

Louis, L., and Heremans, J. (1955). Acta haemat. (Basel), 14, 193.

Soulier, J.-P. (1950). Sang, 21, 37.

Stern, J. R., Mais, R. F., and Boggs, J. D. (1957). Clin. Chem., 3, 599.

Svedberg, T., and Pedersen, K. O. (1940). The Ultracentrifuge. Oxford Unniversity Press, London.

Tsevrenis, H., and Samios, B. G. (1958). Lancet, 1, 266.

Vazquez, J. J. (1958). J. Lab. clin. Med., 51, 271.

Videbaek, A. (1955). Acta med. scand., 153, 459.

Volpś, R., Bruce-Robertson, A., Fletcher, A. A., and Charles, W. B. (1956). Amer. J. Med., 20, 533.

Wajchenberg, B. L., and Hoxter, G. (1955). A.M.A. Arch. Path., 60, 669 .
Waldenström, J. (1944). Acta med. scand., 117, 216.

- (1952). Advanc. intern. Med., 5, 398.

(1954). Acta paediat. (Uppsala), 43, Suppl. 100, p. 87.

(1958). Triangle, 3, 262.

Wall, R. L. (1956). Int. Soc. Haematology, 6th Congress, Boston, p. 288.

Wallenius, G., Trautman, R., Kunkel, H. G., and Franklin, E. C. (1957). J. biol. Chem., 225, 253.

Wallis, A. D. (1950). Ann. intern. Med., 32, 63.

Wanner, J., and Siebenmann, R. (1957). Schweiz. med. Wschr., 87, 1243.

Wertheimer, E., and Stein, L. (1944). J. Lab. clin. Med., 29, 1082.

Wiedermann, D. (1958). Lancet, 1, 798.

Wieme, R. J. (1953). 1 1de Colloq., Sint. Jans Hospital, p. 47.

Witebsky, E., Rose, N. R., and Shulman, S. (1958). Lancet, 1, 808.

Wollensak, J., and Seybold, G. (1956). Z Z. Naturf., 11 в, 588.

Wuhrmann, F. H., Wunderly, C., and Hässig, A. (1950). Brit. J. exp. Path., 31, 507.

Zinneman, H. H., and Hall, W. H. (1954). Ann. intern. Med., 41, 1152.

Zlotnick, A. (1958). Amer. J. Med., 24, 461. 